\title{
REGIONAL FINANCE AND REGIONAL DISPARITIES IN CHINA
}

\author{
By
}

\author{
Jiangang Peng \\ Hunan University
}

Nicolaas Groenewold

The University of Western Australia

\author{
and \\ Jing He \\ Zhangfei Li \\ Yu Yi \\ Hunan University
}




\title{
Regional Finance and Regional Disparities in China
}

\author{
by \\ Jiangang Peng a \\ Nicolaas Groenewold * a,b \\ Jing $\mathrm{He}^{\text {a }}$ \\ Zhangfei $\mathrm{Li}^{\text {a }}$ \\ $\mathrm{Yu} \mathrm{Yi}{ }^{\mathrm{a}}$ \\ ${ }^{a}$ College of Finance, \\ Hunan University, \\ Changsha, Hunan Province, 410079 \\ P. R. China \\ ${ }^{\mathrm{b}}$ Economics Programme, \\ University of Western Australia, \\ Crawley, WA 6009 \\ Australia
}

* Corresponding author; address: Nicolaas Groenewold, Economics Programme, M251, University of Western Australia, Crawley, WA 6009, Australia;

Phone: +61 (8) 64883345 ;

Fax: +61 (8) 6488 1016;

e-mail: nic.groenewold@uwa.edu.au 


\title{
Regional Finance and Regional Disparities in China
}

\begin{abstract}
:
China's growth has been spectacularly high and persistent over the last few decades. However, there have been regular expressions of concern about the uneven distribution of the benefits across regions and, at times, it has been asserted that the regional distribution of available investment funds has played an important role - national financial institutions (mainly state-owned banks) have redirected deposits from the inland to loans to large institutions in the more prosperous coastal regions. At the same time, smaller regionally-focussed institutions are likely to improve the distribution of funds. We use a panel data set disaggregated by province for the years 1986 to 2004 to test these propositions. We employ recent panel unit roots and cointegration tests using data for state-owned bank loans as well as loans by rural credit cooperatives. We find that financial disparities are related to output disparities, that this relationship is positive, that it is stronger for rural credit cooperatives than for state-owned banks and that this relationship is causal in both the long and short runs. A reduction in financial disparities can be expected to lead a narrowing of output disparities in the short run and in the long run with the effect being larger for rural credit cooperatives than for state-owned commercial banks.
\end{abstract}

JEL Codes:

Key words: regional disparities, panel econometrics, regional finance, China 


\section{Introduction}

The phenomenal growth of China's economy over the past three decades or so is well known - real GDP growth in the 25 years since the beginning of economic reforms under Deng Xiaoping has averaged 9.5\% per annum and is set to continue at about this rate for at least another decade according to informed commentators. This rapid growth has been far from smooth, however. Even over the relatively settled period after 1978, the annual growth rate has fluctuated between $3 \%$ and $15 \%$, with fluctuations even larger if we consider the experience of the pre-reform period.

Intertemporal fluctuations in growth is only one facet of the unevenness of China's growth experience - there has also been significant unevenness in the spatial distribution of growth and this has occurred in a number of dimensions. Two of the most important arise from the urban-rural distinction and the regional disaggregation of the country. In this paper we focus on the regional dimension with the regions defined at the level of the provinces.

In the post-1978 period the average annual growth rate has varied from a low of 7.6\% for Qinghai province in the north-west of China to rates over $13 \%$ for the south coastal provinces of Zhejiang, Fujian and Guangdong. Of greater concern than the differences in growth rates is the fact that, by and large, these differences have exacerbated already large disparities in per capita output levels so that by 2005 Qinghai had a per capita GDP of 10,030 yuan compared to that of Zhejiang of 27,369, Fujian of 18,613 and Guangdong of 23,674 . $^{1}$

Not surprisingly, the spatial distribution of economic activity and welfare in general has been the subject of considerable interest both to policy-makers and to academic researchers. Policy-makers have regularly expressed concern about the adverse implications of regional disparities for national cohesion and stability. For example, one of the key issues discussed in the context of the recent fifth plenary session of the $16^{\text {th }}$ Central Committee of the Communist Party was the gap between rich and poor regions which was seen as a major potential source of political instability in a country where the

\footnotetext{
${ }^{1}$ Data for per capita GDP are from State Statistical Bureau, China Statistical Abstract, 2006.
} 
difficulty of holding the empire together has always been a central challenge for political leaders.

Moreover, this has long been recognised in the history of the People's Republic of China. ${ }^{2}$ While the early Five-Year Plans focussed on industrialisation concentrating on the already industrialised north-eastern provinces, from the mid-1960s the Five-Year Plans have regularly recognised the necessity to address the widening disparities in regional output, generally by allocating more investment expenditure to the inland provinces. A decade later, however, in the Fifth Five-Year Plan (1976-1980) there was a shift of focus back to the wealthier coastal region and a policy of unbalanced growth which continued at least until the Seventh Five-Year Plan (1986-1990). More recent Plans have shifted the focus back towards the interior with growing concern about the implications for social instability of dissatisfaction in the poorer inland provinces of large and persistent differences in inter-provincial levels of economic welfare. The policy concern is evidenced by a number of special policies: the Great Western Experiment (announced in 1999 during the Ninth Five-Year Plan), the Resurgence of North-Eastern Old Industry Base and the Stimulation of the Central Region (both during the Tenth Fiveyear Plan) and the Eleventh Five-Year Plan in which there has been a major push to redress the growing regional disparities.

While regional disparities in China have been the subject of continuing policy concern, factors driving regional growth have also been the subject of a considerable research effort, although it is fair to say that much of this has not been primarily motivated by questions about disparities as such but by an interest in the determinants of long-term growth. The issue of growth convergence (whether different countries converge to the same level of per capita income in the long term as predicted by the neoclassical growth model), initially raised by Barro and Sala-i-Martin (1992), has spawned a large and still expanding empirical growth literature. In early contributions to this literature researchers estimated growth equations using large cross-country data bases; more recently they have also used regional data bases such as those available for the Chinese provinces. Since the early literature, the concept of convergence has been

\footnotetext{
${ }^{2}$ For a more extensive discussion of the regional implications of the various Five-Year Plans, see Groenewold et al. (2007b).
} 
generalised to allow for a variety of additional factors which can drive a wedge between inter-country (or inter-regional) long-term growth rates. In this case convergence is said to be conditional on these additional factors.

Additional factors used in the conditional convergence analysis have been many and varied. In the literature using Chinese data they have included standard variables such as physical investment, human capital investment, foreign direct investment, employment growth, technical progress, trade variables and infrastructure. Other conditioning variables which are more specific to China's economy include the interaction between urban/rural and provincial disparities, barriers to labour migration (which have been particularly strong in China's recent history), fiscal decentralisation, regionally-biased policy and geography - some form of coastal-noncoastal dummy variable.

While a wide variety of factors influencing regional growth have been identified in the empirical literature and policy-makers have used a variety of instruments to address regional disparities, financial factors have received little attention by either researchers or policy-makers. This is a significant gap in the literature for two reasons. First, there is a substantial literature in which a well-documented positive relationship between finance and growth in general is the consensus; the recent survey by Levine (2005) has about 300 references in its bibliography and he is able to conclude that the weight of the evidence is in favour of a positive causal influence of finance on growth. The second reason is the common complaint of regional bias in the way in which national financial institutions make funds available for investment. In particular, it is alleged that the large nation-wide banks (mainly state-owned commercial banks) accept deposits in the inland regions but that their lending is biased to the more prosperous coastal provinces, thus siphoning-off funds from the inland and redirecting them to the coast, exacerbating the pre-existing regional differences. Indeed, a recent Chinese-language paper by Yang and $\mathrm{Li}$ (2004) found that credit flows from poor to prosperous regions and from rural to urban centres and argued that uniform credit policies had done nothing to ameliorate this trend so that the necessity for discriminatory polices was clearly indicated. 
In the English-language research literature only the recent paper by Hao (2006) actually includes financial factors in a growth equation estimated using Chinese provincial data. As was true of the earlier growth literature, Hao's interest is primarily in the growth consequences of financial factors rather than the contribution of these factors to regional disparities. In addition, Ying (2000), Demurger, Sachs, Woo, Chang, Bao and Mellinger (2002), and Demurger, Sachs, Woo, Chang and Bao (2002) all mention the problem of the banks siphoning off funds from the inland and redirecting them to the coast. However, none of these papers includes financial variables in their models.

While there is evidence, therefore, of the importance of financial factors for economic growth in general and very limited evidence that this is also true at the regional level, no empirical work has been carried out to specifically analyse the implications of financial factors for the evolution of regional disparities. Our paper aims to address this gap in the literature by modelling output disparities as such and relating them to disparities in the provision of funds for investment. Our primary aim is to examine the argument above that the regionally unequal distribution of funds by nation-wide banks contributes to regional output disparities. In our analysis, the nation-wide banks are represented by the state-owned commercial banks. A secondary aim is to consider the role of smaller, more regionally-focussed institutions and whether disparities in the way in which they provide funds also contributes to output disparities. In particular, we analyse the relationship between disparities in provincial per capita output levels on the one hand and disparities in per capita loans by state-owned banks, per capita loans by rural credit cooperatives and (as a control variable) per capita capital formation, on the other hand.

Our analysis uses recent econometric techniques for non-stationary panels. We use panel unit-roots tests to test for stationarity and, then, panel cointegration tests to investigate cointegration among the four variables. We find evidence of cointegration and finally test for both short-run and long-run causality. We find a positive long-run relationship between output disparities and financial disparities as well as both short-run and long-run causality running from finance to output disparities, lending support to the argument that differences across regions in per capita output are partly caused by the uneven regional provision of credit. Moreover, we find that the effect of reducing 
regional disparities in the rural credit cooperatives' loans will have a larger effect on output disparities than a similar reduction in disparities in loans by state-owned commercial banks. This suggests the tentative policy implication that greater central funding for the cooperatives which reduces the regional disparities in their loans will be a more effective policy than directives to the national banks to improve their lending to poorer regions.

The remainder of the paper is set out as follows. In the next section, we briefly describe the financial system in China, particularly its regional dimensions and justify our choice of variables. Our paper spans several branches of the empirical literature - that on finance and growth, that on regional growth and that on regional disparities and we draw these strands together in section 3. Section 4 presents the data to be used and section 5 contains an explanation of our econometric methods and a discussion of the results of our empirical work. Conclusions are drawn in section 6.

\section{China's financial system}

Historically China's financial system has been dominated by banks, as is the case in many emerging countries. In 1978 at the beginning of the period of economic reform and opening-up, the formal financial system consisted of a single bank, the People's Bank of China (PBC) which accepted deposits and channelled funds according to government credit-allocation policy. Subsequent development saw a considerable increase in diversity of financial institutions as well as the relaxation of directed lending. The reforms began with the development of a two-tier banking system between 1979 and 1993 during which four state-owned banks (SOBs) were established to carry out the PBC's banking business, leaving the PBC as a central bank.

The central government also provided for the establishment of a broader range of banking institutions such as the rural credit cooperatives (RCCs), urban credit cooperatives (UCCs) and small- and medium-sized commercial shareholding banks, all of which were more regionally-focussed than the SOBs. The government encouraged competition between these new institutions and the SOBs, although the latter were still subject to a good deal of policy direction.

In 1994 the SOBs were relieved of their policy-lending obligations with the creation 
of three specialised policy banks which dealt with policy-lending, leaving the SOBs to concentrate on commercial banking. During this period the city commercial banks (CCBs) were allowed to develop.

By 1997 non-performing loans (NPLs) had reached alarming proportions and there followed a period of consolidation and financial restructuring in the Chinese banking system, including the consolidation of $1,658 \mathrm{RCCs}$ into 81 joint stock city or rural commercial banks.

The final distinct stage of institutional diversification began in 2001 and has been largely outward-looking prompted by China's joining the WTO. There was also continued privatisation of the SOBs with two having been listed and the other two in preparation for doing so. Consolidation and rationalisation of existing institutions continues.

As explained above, the credit allocation system was highly centralised before 1978, being arranged through the PBC and its branches according to the credit plan, which was prepared in the form of a source-and-use-of-funds statement to match the estimated demand for physical resources. After 1984 the specialised banks were allowed a limited freedom in the use of funds although they were still obliged to submit projections on loans and deposits to the PBC for approval with credit quotas being strictly enforced. The PBC finally removed credit quotas for the SOBs in 1998, moving instead to the implementation of management principles based on asset-liability ratios.

In addition to the banking system, there is a growing stock market in China. Two stock exchanges, the Shanghai Stock Exchange and the Shenzhen Stock Exchange, were established in 1990 and 1991. A unique feature of the Chinese stock market is the two types of shares, A shares and B shares traded on each exchange. A shares are exclusively sold to Chinese nationals and trade is carried out in local currency. B shares, the first of which were listed on the Shanghai exchange in February 1992, are traded in foreign currencies (Hong Kong dollars in Shenzhen and US dollars in Shanghai) by foreign investors. Since February 2001, domestic investors are also allowed to trade in B shares, although trading is still in terms of foreign currency. In addition to the A and B shares, Chinese companies can issue H shares on the Hong Kong Stock Exchange, N shares on the New York Stock Exchange and S shares on the Singapore Stock Exchange but these 
account for relatively little of their capitalisation. Since the late 1990s many state-owned enterprises (SOEs) have listed but with a large proportion of their shares being nontradable state-owned shares. Despite these rapid developments, the stock exchange still accounts for only a minor proportion of funds raised by business.

All in all, China's financial system has developed steadily since the beginning of reforms in the early 1980s but reform has been cautious and the banks are still by far the most important sources of funds for business expansion. For example, in the first half of 2004, as Zhou Xiaochuan, Governor of the People's Bank of China pointed out, bank loans accounted for as much as $89.5 \%$ of the non-financial businesses' new financing in China. Though the security market of China has achieved a certain degree of development in the more recent part of the reform period and contributed to the enhancement of the proportion of direct financing, banks still enjoy a central position in the provision of finance. Summary statistics capturing some aspects of this situation for 1986 and 2004 (the years which span our sample period) are reported in Table 1. The table shows the dominance of banks compared to the stock market as a source of funds for investment. It also shows the dominance of the SOBs banks even by 2004 after 20 years of reforms designed to diversify financial institutions. Over the early part of our sample the only alternative to the SOBs (with a share of 92\%) was the RRCs (8\%). By 2004 the SOBs' share had fallen to $61 \%$ and the RRCs' had increased to over $12 \%$ and the other major players by then were the joint-stock commercial banks.

\section{Table 1 near here}

Turning to the spatial allocation of loans we discover considerable inequality across regions. Thus, e.g. in 2004, total loans outstanding in the "city-province" of Shanghai were 1,497.2 billion yuan which amounted to a per capita figure of $85,947.2$ yuan; the relatively prosperous coastal province of Guangdong had comparable per capita loans outstanding of 26439.4 yuan while the relatively poor inland provinces of Guizhou and Qinghai were 5210 yuan and 11500 yuan respectively. ${ }^{3}$

More comprehensive information for loans extended by the SOBs and RRCs for

\footnotetext{
${ }^{3}$ The data are from Almanac of China's Finance and Banking, 2005.
} 
2004 is reported in Table 2. A map with China's provinces as divided into the commonly used three regions (coast, centre and west) is shown in Figure 1.

\section{Table 2 near here}

\section{Figure 1 near here}

Several features of Table 2 stand out. First, a simple inspection of the variation of all three series across provinces shows very considerable inter-regional differences. The first column of figures shows the ratio of each province's per capita real GDP to its national counterpart. The next two columns show a similar ratio for SOBs' loans and loans by RRCs. The GDP column shows figures ranging from over 8 (for Shanghai) to barely $25 \%$ (for Guizhou). The ratios are the highest for the coastal "city-provinces" of Beijing (3.8), Shanghai (8.2) and Tianjin (3.6) followed by the coastal provinces of Fujian, Guangdong, Jiangsu, Liaoning, Shandong and Zhejiang. Apart from Neimenggu (an outlier for political reasons), all interior provinces have a ratio less than one and many of them considerably so. A summary dispersion measure is given by the coefficient of variation $(\mathrm{CV})$ in the last row of the table. It shows that the standard deviation of per capita real GDP across provinces exceeded the mean by about 5\%; to put it into context, a similar figure for the US states is $0.37 .^{4}$

The figures for loans also show considerable regional variation. Indeed, the CV for per capita SOB loans is greater than it is for per capita real GDP, while it is smaller for loans extended by RRCs. A casual inspection of the data show that there seems to be a strong relationship between disparities in real GDP and those in loans and this is confirmed by the correlations in the second-last row: the correlation of per capita SOB loans with per capita real GDP is almost perfect (96\%) and, while that for RRCs is lower, it is still considerable at $88 \%$. These show that there is a strong relationship between inequalities in these variables but that there is a stronger effect for SOB loans than for those by RRCs, not surprisingly since the latter were specially designed to overcome the perceived lack of funding available for the poorer regions. However, while these data are consistent with the assertion that disparities in the regional allocation of loans is one of

\footnotetext{
${ }^{4}$ Based on state real GDP for 2005 at 2000 prices.
} 
the factors driving inequalities in regional development, correlation is not causation, a matter to which we turn in the statistical analysis below where we subject the assertion to more formal statistical testing.

\section{Literature Review}

Our paper is related to three closely connected literatures. The first and most general is the empirical growth literature. We briefly review this before turning to two specialisations of this literature - that on the relationship between finance and growth and based on regional data sets, especially panel data for the Chinese provinces. We finally survey the limited literature on regional disparities in China.

The empirical literature on long-term economic growth has expanded rapidly following the path-breaking paper by Barro and Sala-i-Martin (1992) which introduced the concept of "convergence", although this was based on earlier work by Kuznets (1955) and the subsequent empirical work by Williamson (1965) and Baumol (1986). The essential idea of convergence is straightforward: in the simple neoclassical growth model all countries converge to their balanced growth path on which steady-state income per capita is independent of the initial conditions. Hence, no matter what the inherited differences in capital stock are, countries converge to the same rate of growth and to the same level of income per capita. In fact, countries may differ in growth rates but these differences will reflect countries' being at different distances from their balanced growth paths.

The initial tests of convergence were based on estimated growth equations using cross-country data sets. Thus, in one of the early papers, Baumol (1986) used data for 16 industrialised countries for 1870 and 1979 and found strong evidence for convergence. This evidence was not uncontroversial and subsequent analysis, partly based on the new "endogenous growth" theory (see, e.g. Aghion and Howitt, 1998), introduced additional factors which explained differences in long-term growth rates between countries and so introduced the concept of conditional convergence. Common conditioning variables included investment in human capital, measures of international trade, foreign direct investment and so on.

One set of conditioning variables which has produced a substantial literature in its 
own right are various measures of the nature and development of the financial system. The finance and growth literature has expanded rapidly since the mid 1990s and has been recently surveyed by Levine (2005). Early studies based on the work of McKinnon (1973) and Shaw (1973) was generally optimistic about the beneficial growth effects of the removal of constraints on a country's financial system (see, e.g., Kapur, 1976, Galbis, 1977, Mathieson, 1980 and Fry, 1980) although there are dissenters such as the Neostructuralists (Taylor, 1983, van Wijnbergen, 1982, 1983a, 1983b, and Stiglitz and Weiss, 1981).

Subsequent work based on large cross-country panel data sets such as the influential study by King and Levine (1993) found general support for a positive effect of finance on growth. Subsequent work by Amable, Chatelain and de Bandt (2002), Bencivenga and Smith (1991), Bencivenga et al. (1995), Benhabib and Spiegel (2000) and La Porta et al. (2002) generally supported the King and Levine results although extensions to include stock market development by Atje and Jovanovic (1993) and Levine and Zervos (1998) and bond markets by Fink et al. (2003) produced results which show a weaker relationship between development of these markets and economic growth. While more recent work has examined questions of causality more closely, Levine is able to conclude that "a growing body of empirical analyses ... demonstrate a strong positive link between the functioning of the financial system and long-term economic growth" (Levine, 2005, p.921).

A second specialisation of the empirical growth literature is to that which uses panel data sets based, not on cross-country data, but on regions of a particular country. Given the increasing availability of data for the Chinese provinces, Chinese data have become widely used in this area in the past decade. While it has generally been motivated by the convergence debate, it has also been able to throw light on the factors influencing regional growth in China. In terms of the conditional convergence model, a large number of different conditioning variables have been used in the empirical literature using Chinese provincial data; they include ones traditionally used in the convergence literature in general such as physical investment, human capital investment, foreign direct investment, employment growth (Chen and Fleisher, 1996), technical progress (Fleisher and Chen, 1997, Lai, Peng and Bao, 2006), trade variables (Yao and Zhang, 2001a, Yao, 
2006) and infrastructure (Demurger, 2001) as well as variables more specific to China's economy such as the interaction between urban/rural and provincial disparities (Kanbur and Zhang, 1999, Chang, 2002, Lu, 2002), barriers to labour migration (Lu, 2002, Cai, Wang and Du, 2002), fiscal decentralisation (Jin and Zou, 2005 and Zhang, 2006), region-biased policy (Yang, 2002, Bao, Chang, Sachs and Woo, 2002, Demurger, Sachs, Woo, Bao, Chang and Mellinger, 2002, and Demurger, Sachs, Woo, Bao and Chang, 2002) and geography - some form of coastal/noncoastal dummy variable has been used by many authors and geography has received specific attention in such papers as Yao and Zhang (2001b), Bao, Chang, Sachs and Woo (2002), Demurger, Sachs, Woo, Bao, Chang and Mellinger (2002) and Demurger, Sachs, Woo, Bao and Chang (2002).

Despite the general importance of finance for growth and the plethora of conditioning variables in studies using Chinese provincial data, there is almost none that combines the two; only the recent paper by Hao (2006) uses measures of financial development in a Chinese panel data setting. In that paper three financial variables are used: the ratio of state bank loans to GDP, the ratio of household deposits to GDP and the ratio of investment financed by domestic loans to those financed from the state budget. In line with the general finance-growth literature, Hao finds that "the development of financial intermediation exerts a positive, causal and economically large impact on China's economic growth" (Hao, 2006, p.261).

The third literature to which our work is related is that on regional disparities. Given the pervasiveness of regional disparities, it is not surprising that regional scientists have subjected them to a good deal of analysis using a wide variety of methods. Interest in this area of regional analysis continues - recent papers have analysed disparities in a variety of countries and variables and used a variety of methods - convergence has been a popular framework (see Silveira-Netto and Azzoni, 2006, Petrakis and Seratsis, 2000, Bode and Rey, 2006, Ying, 2006, Beenstock and Felsenstein, 2007 and Coulombe, 2007), methods have varied from growth equations used in many of the references just cited, growth accounting (DiGiacinto and Nuzzo, 2006), spatial data analysis (Gallo and Artur, 2003, Garrett, Wagner and Wheelock, 2007, and Ertur and Koch, 2006), shift-share analysis (Blien and Wolf, 2003) to vector-autoregressive models (Groenewold, Lee and 
Chen, 2007a, 2007b). Countries covered in these papers include Greece, Israel, Brazil, Canada, Italy, the USA and China.

While disparities in general have been widely analysed, studies of regional disparities in China have been more limited in number. Although studies of China's growth based on regional data sets may be used to throw light on disparities, they are often not motivated by disparities but rather by the growth-convergence debate. There have, of course, been many studies of regional disparities in China in general, addressing especially the issue of whether such disparities have increased or not over the 30 years since reforms began; see Wu (2004), Wan and Zhang (2006) and Heilig (2006) for recent discussions and references. But very few studies have modelled disparities as such. An interesting recent exception is the paper by Pedroni and Yao (2006) who directly model the deviations of provincial per capita output from the national average and, using recent advances in econometric methods for non-stationary panels, address the stationarity of these disparities for various groupings of the provinces, according to geographic location and as to whether they have been the subject of preferential central government policies.

The work reported in this paper draws on the regional disparity literature by explicitly modelling disparities as Pedroni and Yao (2006) do but does so following the finance and growth literature by modelling the disparities directly in terms of disparities of financial variables of the sort used in the finance and growth research. Like much of the growth literature, we use a panel data set based on provinces as the cross-section unit.

In particular, we use a simple model which explains per capita output in terms of two financial variables: per capita loans provided by state-owned commercial banks and per capita loans provided by rural credit cooperatives as well as a control variable for other influences, per capita capital formation. Following Pedroni and Yao (2006), we cast the model in terms of deviations from the national average for each variable and like them, we too pay attention to the issues of stationarity using recently developed methods for panels. However, since we analyse a multi-variate model, we need to extend their analysis to the application of panel cointegration tests and a consideration of long-run and short-run causality within the framework of a cointegrated panel.

\section{The data}


As stated in section 1, the aim of this paper is, first, to test the common assertion that regional imbalances in the distribution of loans is one of the causes of inter-regional output disparities and, as a secondary aim, to assess the different impacts on output disparities in loans by the large state-owned commercial banks on the one hand, and small to medium financial institutions on the other. We will do this by a statistical analysis of the relationship between loans and output using a panel data set whose crosssection is based on provinces and whose time dimension runs from 1986 to 2004 .

Evidence presented in section 2 showed that the state-owned commercial banks have dominated and continue to dominate the financial landscape in China and that by the end of the sample the main alternatives were the joint-stock commercial banks and the rural credit cooperatives. Of these two, only the latter have operated throughout our sample period and they also fit our secondary aim of assessing the impact of loans by financial institutions which are more regionally sensitive, with the joint-stock commercial banks operating more like the state-owned commercial banks than the rural cooperatives. Given our vector-autoregressive modelling strategy (of which more below), it was impossible to include more than two financial variables in our model and we decided to use loans by the state-owned commercial banks and loans by rural credit cooperatives. The remaining two variables are real GDP and real capital formation as a standard control variable in growth equations. We therefore used data for four variables: real per capita GDP, real per capita capital formation and real per capita values of the two loan variables.

There are various ways in which we could specify the model - as a standard growth model following the literature reviewed in section 3, or in levels or logs of output, capital formation and loans. All of these formulations would, however, have allowed us to make only indirect inferences about inter-regional disparities. Instead we opted for a more direct approach and followed Pedroni and Yao (2006) and specified the model directly in the variables of interest - disparities between individual provincial levels and the national counterpart. To accommodate differences in the size of provinces we used all variables in per capita form. Specifically, our model is specified in terms of the following four variables:

- $\operatorname{drg}_{i t}=$ the deviation of province i's per capita real GDP from national per capita 
real GDP in year $\mathrm{t}$,

- $\mathrm{drs}_{\mathrm{it}}=$ the deviation of per capita real loans extended by stated-owned commercial banks in province $\mathrm{i}$ from the level of per capita real loans by state-owned commercial banks for the nation as a whole in year $\mathrm{t}$,

- $\mathrm{drr}_{\mathrm{it}}=$ the deviation of per capita real loans extended by rural credit cooperatives in province $\mathrm{i}$ from the level of per capita real loans extended by rural credit cooperatives for the nation as a whole in year $\mathrm{t}$, and

- $\mathrm{drk}_{\mathrm{it}}=$ the deviation of per capita real capital formation in province $\mathrm{i}$ from the national level of per capita real capital formation in year $t$

The data for drg and drk were taken from various issues of China Statistical Yearbook and those for drs and drr from various issues of the Almanac of China's Finance and Banking.

\section{The results}

\subsection{Panel stationarity tests}

We now turn to our results and begin by assessing the stationarity of our four variables. Since we use panel data, tests for a unit root applicable to panel data are used. They are carried out within the framework of the following set of equations:

$$
\Delta y_{i t}=\beta_{i 0}+\beta_{i 1} y_{i t-1}+\beta_{i 2} t+\sum_{j=1}^{p} \delta_{i j} \Delta y_{i t-j}+\varepsilon_{i t}, i=1,2, \ldots, N, t=1,2, \ldots, T
$$

where $y$ is the variable of interest, $i$ indexes the $N$ provinces and $t$ the $T$ years. The process generating $y_{i}$ is said to have a unit root if the parameter, $\beta_{i l}$, equals zero and tests of stationarity involve tests of the significance of this crucial parameter. Panel-based tests for stationarity broadly fall into two categories, the first of which assumes that the $\beta_{i 1}$ parameters are common to all cross-section units, i.e., that $\beta_{i 1}=\beta_{1}$ for all $i$. The second category of tests allows this parameter to vary cross-sectionally. Preliminary inspection of equations of the form of (1) provided strong evidence of heterogeneity so that we used two tests in the second category, both of which are based on the augmented Dickey-Fuller (ADF) test of stationarity applied to each province individually. The first is the IPS test (see Im, Pesaran and Shin, 2003) which is based on an average of individual ADF statistics and the second is the Fisher-ADF test due to Maddala and Wu 
(1999) and Choi (2001) which involves the combination of the marginal significance values for the individual cross-sectional ADF tests using a result due to Fisher (1932). The results are reported in Table 3. The test statistics were computed using a lag length of three ( $p=3$ in equation (1)) and are reported both with and without a trend term. Marginal significance values are given in parentheses.

\section{Table 3 about here}

The results are very clear-cut: for each of the disparity variables the null hypothesis of a unit root cannot be rejected so that each is clearly non-stationary. Firstdifferencing the variables makes each clearly stationary - the non-stationary null can be rejected in all cases, mostly at the $1 \%$ level of significance. The results reported in Table 3 are based on lag length chosen by the Schwarz Information Criterion and set at three in all cases. Variation in lag length did not change the results of tests for the stationarity of the disparities and changed the outcome of only one of the tests for the first differences. Hence we conclude that all four disparities are integrated of order 1, I(1), and proceed to a consideration of cointegration.

\subsection{Panel cointegration tests}

A large number of panel cointegration tests has recently become available. They are of two types, one being an extension of the Engle-Granger test to panel data and the other being an application of the Fisher (1932) idea to the marginal probabilities derived from Johansen tests of cointegration applied to the time series for each of the crosssection units. In the first group are various tests due to Pedroni (see Pedroni, 1999, 2004) and to Kao (1999). The Pedroni tests for $m$ variables are based on the following equation:

$$
y_{i 1 t}=\beta_{i 0}+\beta_{i 1} t+\sum_{j=2}^{m} \beta_{i j} y_{i j t}+\varepsilon_{i t}, \quad i=1,2, \ldots, N, t=1,2, \ldots, T
$$

If the $y_{j}$ s are cointegrated the error terms, $\varepsilon_{i t}$, will be stationary so that the test proceeds, following Engle and Granger (1987), in two stages: the estimation of an equation of the form of (2) for each province and then testing the residuals from these estimated equations for stationarity on the basis of second-stage regression of the residuals against lagged residuals. Pedroni developed two different testing procedures depending on 
whether the first-order autocorrelation coefficient in the second-stage regression is constrained to be the same for all cross-section units (the group tests) or whether these coefficients are allowed to vary across cross-section units (the panel tests). The test by Kao is similar in that it is based on the Engle-Granger approach and resembles the group tests of Pedroni in that the first-order autocorrelation coefficient is constrained to be the same across all cross-section units.

The second type of panel cointegration test is due to Maddala and Wu (1999). It proceeds by applying the widely-used Johansen test for cointegration to each crosssection unit individually and then combining the marginal significance values for each of these to arrive at a single p-value.

Pedroni (2004) has shown that the test results can be quite sensitive to test specification in small samples such as ours is (his small samples have $\mathrm{N}=20$ and $\mathrm{T}=30$ while ours has $\mathrm{N}=27$ and $\mathrm{T}=19$ ). Hence, to avoid our results being based on a single test which may be misleading for our sample size, we apply a range of tests. The results are reported in Table 4.

\section{Table 4 near here}

While the results are somewhat mixed, the evidence points clearly in the direction of cointegration. All but two of the Pedroni tests allow us to reject the null hypothesis of no cointegration, the exceptions both being based on the Phillips-Perron (PP) test of stationarity of the residuals. This may reflect the unreliability of the PP test in short timeseries samples. The majority verdict of the Pedroni tests is confirmed by the Kao test. The tests based on the application of the Johansen test to the individual provincial time series allow for more than one cointegrating vector - for our four variables there will be a maximum of three such vectors. As with the standard Johansen test, two versions are available, the trace and the eigenvalue tests shown in the table. They both require the rejection of no cointegration as well as the rejection that there is at most one cointegrating vector. The hypothesis that there are at most two cointegrating vectors cannot be rejected at 5\% for the eigenvalue test. Thus the Fisher-Johansen procedure points strongly to cointegration and suggests that there may be more than one cointegrating vector. An inspection of the individual cross-section results shows that the hypothesis of exactly one cointegrating vector holds for about half the provinces. The 
hypothesis that there are three cointegrating vectors is rejected for all but two of the provinces when tested individually.

On the whole, therefore, the evidence points strongly to the cointegration of the disparities in per capita real output, per capita loans extended by the state-owned commercial banks and by the rural credit cooperatives and per capita capital formation and we proceed to model these four variables as a cointegrated system.

\subsection{Estimated the cointegrating vector}

The finding that our four disparity variables are cointegrated implies that there is a long-run relationship between them and this is given by the cointegrating vector which we estimate as the cointegrating regression. The estimated cointegrating regression is the basis of the cointegration tests reported in Table 4. However all these tests (except Kao's) allow for different cointegrating regressions for each province and an inspection of the result shows considerable variability making interpretation difficult. To obtain an estimate of an overall relationship between the financial disparities and output disparities, we estimate a common cointegrating regression. If we use OLS to estimate a common cointegrating equation but allow for fixed effects and fixed time effects, we obtain the following equation (with t-statistics in parentheses and omitting the fixed effects):

$$
d r g_{i t}=0.4205 d r k_{i t}+1.6317 d r r_{i t}+0.3709 d r s_{i t}
$$

The estimated coefficients are clearly all significantly different from zero and of the expected sign; in particular, disparities in the provision of loans by both state-owned commercial banks and by rural credit cooperatives are positively related to the disparities in per capita GDP with the coefficient on the rural credit cooperatives variable being larger. An alternative estimator to OLS is Pedroni's (2000, 2001) group-mean panel Fully Modified OLS (FMOLS) estimator for heterogeneous panels. In Monte Carlo simulations, Pedroni (2000) finds this estimator and the related t-test to perform relatively well even in small panels with considerable cross-section heterogeneity (which we observed above to characterise our data). If we apply this procedure with time dummy variables, the estimated coefficients are of a similar order of magnitude to those reported 
above. In this case the long-run equation is (again omitting the deterministic components):

$$
d r g_{i t}=0.7270 d r k_{i t}+1.2793 d r r_{i t}+0.2146 d r s_{i t}
$$

Hence, as we found above, all variables are clearly significant and positive. Moreover, the relative magnitudes of the coefficients correspond to the pooled OLS estimates. We can conclude tentatively, that in the long run a reduction in the average disparity across provinces of the provision of loans by rural credit cooperatives will have a larger impact on regional output disparities than a similar reduction in the average disparity of stateowned bank loans across provinces, other things being equal.

However, other things may not be equal. In particular, in principle all four variables are endogenous so that changes in one of the right-hand-side variables will not necessary be felt only in the left-hand-side variable - the other regressors in the cointegrating regression may also be affected and so offset or, indeed, reinforce the original effect. To address this issue we need to consider causality to which we now turn.

\subsection{Testing long-run causality}

In the case of cointegrated variables, we can distinguish two forms of causality long-run and short-run where the former is a property of the long-run cointegrating relationship and the latter pertains to the short-run dynamic adjustment of the system to a long-run equilibrium.

Consider long-run causality first. Long-run causality in panels has been analysed in a pair of recent unpublished papers by Canning and Pedroni $(1999,2004)$. They say that one variable has a long-run causative effect on another if a shock to the first has a permanent effect on the second which is clearly relevant only to integrated variables ( and to variables which are cointegrated so that a long-run relationship exists between them). The Canning and Pedroni test is simple to apply since it involves the significance testing of the error correction coefficient in one of the equations of the panel VECM. It is unfortunately applicable only to cointegrating relationships between two variables and 
also requires a prior theoretical restriction on the coefficients of the model. ${ }^{5}$ It is therefore, not applicable to our model which has four variables.

We therefore use the more general method by Toda and Yamamoto (1995) even though it is not specifically designed for models estimated on panel data sets. It proceeds in terms of a vector-autoregressive (VAR) model specified in the levels of the cointegrated variables even though they are non-stationary. If the VAR in the levels of the variables has known order of $\mathrm{k}$ and the highest degree of integration of the variables is $\mathrm{d}$, a $\operatorname{VAR}(\mathrm{k}+\mathrm{d})$ is specified, estimated by OLS and standard tests for causality are carried out but using only the first $\mathrm{k}$ lags.

We apply this to our panel by estimating a VAR model in the four variables for each province and testing the significance of the relevant coefficients across all provinces. Thus in the $\operatorname{VAR}(\mathrm{k})$ model for four I(1) variables we estimate a model with $k+1$ lags:

$$
\begin{aligned}
& d r g_{i t}=\mu_{i 1}+\sum_{j=1}^{k+1}\left(\alpha_{i 1 j} d r g_{i t-j}+\beta_{i 1 j} d r k_{i t-j}+\delta_{i 1 j} d r r_{i t-j}+\gamma_{i 1 j} d r s_{i t-j}\right)+\varepsilon_{i 1 t} \\
& d r k_{i t}=\mu_{i 2}+\sum_{j=1}^{k+1}\left(\alpha_{i 2 j} d r g_{i t-j}+\beta_{i 2 j} d r k_{i t-j}+\delta_{i 2 j} d r r_{i t-j}+\gamma_{i 2 j} d r s_{i t-j}\right)+\varepsilon_{i 2 t} \\
& d r r_{i t}=\mu_{i 3}+\sum_{j=1}^{k+1}\left(\alpha_{i 3 j} d r g_{i t-j}+\beta_{i 3 j} d r k_{i t-j}+\delta_{i 3 j} d r r_{i t-j}+\gamma_{i 3 j} d r s_{i t-j}\right)+\varepsilon_{i 3 t} \\
& d r s_{i t}=\mu_{i 4}+\sum_{j=1}^{k+1}\left(\alpha_{i 4 j} d r g_{i t-j}+\beta_{i 4 j} d r k_{i t-j}+\delta_{i 4 j} d r r_{i t-j}+\gamma_{i 4 j} d r s_{i t-j}\right)+\varepsilon_{i 4 t}
\end{aligned}
$$

To test, for example, that $d r r$ causes $d r g$ in the long run we test $\mathrm{H}_{0}: \delta_{i l j}=0$, for $i=1$, $2, \ldots, \mathrm{N}$, and $j=1,2, \ldots, k$ (so ignoring the last lag in each case) using a Wald test. The Wald statistic has a $\chi^{2}$ distribution with $\mathrm{Nk}$ degrees of freedom. Note that for this test we need estimate only equation (5a).

Before applying the test we need to decide how to determine the lag length, $k$, since the test is derived on the basis of known lag length. Toda and Yamamoto (1995) show that we can use standard procedures to determine the lag length of the VAR. They use standard hypothesis testing procedure to pare the lag length down from a particular

\footnotetext{
${ }^{5}$ This, not withstanding the application by Lee (2005) and Lee and Chang (2007) to models in three variables with no apparent use of the prior restrictions.
} 
maximum. In a recent application of this test by Soytas et al. (2007), a number of standard diagnostic tests for the equations such as tests for autocorrelation, heteroskedasticity and functional form are also used to determine specification.

In the light of the above, we proceeded as follows. We entertained a maximum value of $k$ of two since a value of $k$ of three would require the estimation of a VAR(4) to run the tests and, with four variables as well as (possibly) a trend and intercept this would have exhausted our degrees of freedom since we have 19 observation in our time-series dimension. For a system-wide test of VAR(2) versus VAR(1), the restriction implied by VAR(1) was clearly rejected. This was also the case when we tested just within the framework of the $d r g$ equation although the standard lag-length criteria such as the Akaike Information Criterion, the Schwarz Information Criterion and the Hannan-Quinn Criterion gave conflicting indications: two of them suggested a VAR(1). Given this ambiguity we experimented with both VAR(1) and VAR(2) specifications. We also had to decide whether to allow coefficients to vary across provinces or to constrain them to be equal. Given four variables, as well as an intercept and possibly a trend, this left a lot of flexibility. We began by conducting the causality tests in a wide variety of settings. Unfortunately, as shown in Table 5, the results were highly sensitive to specification.

\section{Table 5 about here}

The tests show that for $k=1, d r k$ generally causes $d r g$ in the long run but that evidence for causality is less strong for the case when $k=2$. For the other two variables the evidence of causality tends to be stronger when $k=2$ although even then it depends crucially on other aspects of specification. It is clear, therefore, that the specification needs to be tested carefully.

Since the causality test uses only the $d r g$ equation, we focussed on this equation in conducting the specification tests. We began our specification testing with the most general case, the one captured in the last line of the table and first tested for one lag versus two for all variables. The restriction from two to one lag using a standard F-test for variable exclusion, produces a value of $\mathrm{F}(108,189)$ of 1.6825 which has a p-value of 0.0009 , thus clearly supporting the use of a value of two for $k$. We therefore carried out further tests using a model with two lags. 
It is clear from Table 5 that the presence of the trend terms is crucial for the outcomes of the causality tests and we next tested for the joint significance of the trend coefficients. The F-statistic in this case was $\mathrm{F}(27,54)=4.5341$ which has a p-value of 0.0000 , clearly indicating that the trends belong in the model. The form of the trend (common or individual) is still open and we next tested this using a likelihood ratio test of a model with common trends against one where the trend coefficients are allowed to vary cross-sectionally. The likelihood ratio which is $\chi^{2}(26)$-distributed under the null of common coefficients has a value of 507.85 with a corresponding p-value of 0.0000 providing strong support for individual trend terms.

A similar test was carried out for a comparison of a common intercept versus individual intercepts; the $\chi^{2}(26)$ statistic has a value of 525.86 in this case, also with a pvalue of 0.0000 . Finally, we tested for common coefficients for the remaining regressors - the lags of $d r g, d r k, d r r$ and $d r s$ - the restriction for which was also strongly rejected with a $\chi^{2}(78)$ value of 1094.21 and a p-value of 0.0000 .

Thus, despite the apparent ambiguity in the results reported in Table 5, the outcome of the tests for causality running from $d r k, d r r$ and $d r s$ to $d r g$ are quite clear - in the model strongly indicated by our specification tests, all three variables clearly cause output disparities in the long run. In particular, regional disparities in loans by both stateowned commercial banks and rural credit cooperatives contributein the long run to real output disparities across provinces. The magnitude of the effects is difficult to tell from inspection of the results since there are 27 coefficients for each of two lags of the two financial variables. Averaging these over all provinces and across both lags suggests that effects are considerably larger for the rural credit cooperatives than for the state-owned banks confirming the implications of the estimated cointegrating regressions reported in equation (4). The averages are also similar in magnitude to those derived from estimating the model with common coefficients. The outcome of the Toda-Yamamoto test therefore provides clear evidence that disparities in both types of loans have significant long-run causal effects on disparities in GDP but that the magnitude of the effect for rural credit cooperatives is larger than for state-owned banks.

\subsection{Testing short-run causality}


Our final exercise is to test for more conventional short-run causality within the context of a VECM which is implied by the presence of cointegration between our four disparity variables. In this case we estimate a standard VECM for each province (given our conclusions regarding the heterogeneity of the cointegrating vector reached earlier) and test the cross-equation restrictions implied by the absence of causality jointly for all provinces. In particular, the model used is (again omitting deterministic components):

(6a) $\Delta d r g_{i t}=\mu_{i 1} \phi_{i t-1}+\sum_{j=1}^{p}\left(\alpha_{i 1 j} \Delta d r g_{i t-j}+\beta_{i 1 j} \Delta d r k_{i t-j}+\delta_{i 1 j} \Delta d r r_{i t-j}+\gamma_{i 1 j} \Delta d r s_{i t-j}\right)+\varepsilon_{i 1 t}$

(6b) $\Delta d r k_{i t}=\mu_{i 2} \cdot \phi_{i t-1}+\sum_{j=1}^{p}\left(\alpha_{i 2 j} \Delta d r g_{i t-j}+\beta_{i 2 j} \Delta d r k_{i t-j}+\delta_{i 2 j} \Delta d r r_{i t-j}+\gamma_{i 2 j} \Delta d r s_{i t-j}\right)+\varepsilon_{i 2 t}$

(6c) $\Delta d r r_{i t}=\mu_{i 3} \cdot \phi_{i t-1}+\sum_{j=1}^{p}\left(\alpha_{i 3 j} \Delta d r g_{i t-j}+\beta_{i 3 j} \Delta d r k_{i t-j}+\delta_{i 3 j} \Delta d r r_{i t-j}+\gamma_{i 3 j} \Delta d r s_{i t-j}\right)+\varepsilon_{i 3 t}$

(6d) $\Delta d r s_{i t}=\mu_{i 4} \cdot \phi_{i t-1}+\sum_{j=1}^{p}\left(\alpha_{i 4 j} \Delta d r g_{i t-j}+\beta_{i 4 j} \Delta d r k_{i t-j}+\delta_{i 4 j} \Delta d r r_{i t-j}+\gamma_{i 4 j} \Delta d r s_{i t-j}\right)+\varepsilon_{i 4 t}$

where $\phi_{i t}$ is the (estimated) cointegrating vector for province $\mathrm{i}$ in period $\mathrm{t}$. The test for short-run causality from, say, $d r k$ to $d r g$ tests the significance of the lagged $\Delta d r k$ terms in the $\Delta d r g$ equation and so uses only equation (6a). We conducted this test for each of $\Delta d r k, \Delta d r r$ and $\Delta d r s$ in the $\Delta d r g$ equation. The estimated cointegrating vectors were obtained from the Johansen estimates used in the cointegration tests based on the Johansen procedure described above and included a constant and a trend term. The number of lags, $p$, was chosen to be one, following our conclusion above that the VAR in levels has a lag length of two. The results are reported in Table 6 .

\section{Table 6 near here}

The table provides strong evidence of short-run causation from each of the two financial disparities to the disparity in per capita output. This confirms the long-run results so that we may conclude that the relationship we discovered between financial and output disparities is not simply correlation but reflects causation (at least in the Granger sense) in both the short run and the long run.

\section{Conclusions}


The analysis presented in this paper was motivated by the oft-heard but little researched complaint that output disparities between provinces in China are at least partly the result of the financial system (dominated by the large state-owned commercial banks) which siphons funds from the inland provinces and lends them to large firms in the more prosperous coastal provinces. Moreover, it is likely that smaller regionally-focussed institutions such as rural credit cooperatives are more effective in addressing regional inequalities.

While there is a large literature which uses Chinese regional data to investigate the sources of economic growth and, in particular, to test the convergence hypothesis, there is almost no literature which tests the influence of financial factors on growth and the single paper we have been able to find is not directed specifically at the disparities question. Our paper goes some way to filling this gap in the literature setting out a model specifically in terms of disparities and we found strong evidence to support the complaint above. Disparities between output, rural-credit-cooperative loans, state-owned bank loans and capital formation were found to be non-stationary but cointegrated so that a long-run equilibrium relationship exists among these variables. Estimates of the long-run relationship show a positive and significant relationship between both financial disparities and the disparity in per capita output. The influence of rural credit cooperative was found to be considerably larger than that of the state-owned banks suggesting that extension of the operation of these institutions and greater funding for them in poor regions will considerably improve the regional distribution of output.

Further investigation of this relationship shows that it is causal in both the short and long runs - in both cases changes in disparities in loans across provinces would be expected to lead to changes in output disparities. The long-run results show again that a reduction in the regional disparities in loans by rural credit cooperatives will have a greater effect on output disparities than a similar change in the loans by state-owned banks. 


\section{References}

Aghion, P. and P. W. Howitt (1998), Endogenous Growth Theory, MIT Press, Cambridge, Massachusetts.

Amable, B., Chatelain, J.B. and de Bandt, O. (2002), 'Optimal Capacity in the Banking Sector and Economic Growth', Journal of Banking and Finance, 26, 491-517.

Atje, R. and Jovanovic, B. (1993), 'Stock Markets and Development', European Economic Review, 37, 632-640.

Bao, S., G. H. Chang, J. D. Sachs and W. T. Woo (2002), "Geographic Factors and China's Regional Development under Market Reforms, 1978-1998”, China Economic Review, 13, 89-111.

Barro, R. J. and X. Sala-i-Martin (1992), “Convergence”, Journal of Political Economy, $100,223-251$.

Baumol, W. (1986), " Productivity Growth, Convergence and Welfare”, American Economic Review, 76, 1072-1085.

Beenstock, M. and D. Felsenstein (2007), "Mobility and Mean Reversion in the Dynamics of Regional Inequality”, International Regional Science Review, 30, 335-361.

Bencivenga, V.R., and Smith, B.D. (1991), 'Financial Intermediation and Endogenous Growth', Review of Economics Studies, 58, 195-209.

Bencivenga, V.R., Smith, B.D.S. and Starr, R.M. (1995), 'Transactions Costs, Technological Choice, and Endogenous Growth', Journal of Economic Theory, 67, 53-177.

Benhabib, J. and Spiegel, M.M. (2000), 'The Role of Financial Development in Growth and Investment', Journal of Economic Growth, 5, 341-360.

Blien, U. and K. Wolf (2002), "Regional Development of Employment in Eastern Germany: An Analysis with an Econometric Analogue of Shift-share Techniques”, Papers in Regional Science, 81, 391-414.

Bode, E. and S. J. Rey (2006), “ The Spatial Dimension of Economic Growth and Convergence", Papers in Regional Science, 85, 171-176.

Cai, F., D. Wang and Y. Du (2002), "Regional Disparity and Economic Growth in China: The Impact of Labor Market Distortions”, China Economic Review, 13, 197-212. 
Canning, D. and P. Pedroni (1999), "Infrastructure and Long Run Economic Growth", Discussion Paper, Indiana University.

Canning, D. and P. Pedroni (2004), "The Effect of Infrastructure on Long Run Economic Growth", Discussion Paper, Williams College.

Chang, G. H. (2002), “The Cause and Cure of China's Widening Income Disparity", China Economic Review, 13, 335-340.

Chen, J. and B. M. Fleisher (1996), "Regional Inequality and Economic Growth in China", Journal of Comparative Economics, 22, 141-164.

Choi, I. (2001), “ Unit Root Tests for Panel Data”, Journal of International Money and Finance, 20, 249-72.

Coulombe, S. (2007), "Globalization and Regional Disparity: A Canadian Case Study", Regional Studies, 41, 1-17.

Demurger, S. (2001), "Infrastructure Development and Economic Growth: An Explanation for Regional Disparities in China?", Journal of Comparative Economics, 29, 95-117.

Demurger, S., J. D. Sachs, W. T. Woo, S. Bao, G. Chang and A. Mellinger. (2002), "Geography, Economic Policy and Regional Development in China", NBER Working Paper 8897, April 2002.

Demurger, S., J. D. Sachs, W. T. Woo, S. Bao and G. Chang. (2002), "The Relative Contributions of Location and Preferential Policies in China's Regional Development: Being in the Right Place and Having the Right Incentives", China Economic Review, 13, 444-465.

DiGiacinto, V. and G. Nuzzo (2006), "Explaining Labour Productivity Differentials across Italian Regions: The Role of Socio-Economic Structure and Factor Endowments”, Papers in Regional Science, 86, 299-320.

Engle. R. F. and C. W. J. Granger (1987), “ Co-Integration and Error Correction: Representation, Estimation and Testing”, Econometrica, 55, 251-276.

Ertur, C. and W. Koch (2006), " Regional Disparities in the European Union and the Enlargement Process: An Exploratory Spatial Data Analysis, 1995-2000”, Annals of Regional Science, 40, 723-765. 
Fink, G., Haiss, P. and Hristoforova, S. (2003), 'Bond Markets and Economic Growth', Research Institute for European Affairs, Working Paper 49.

Fisher, R. A. (1932), Statistical Methods for Research Workers, $4^{\text {th }}$ ed., Edinburgh, Oliver and Boyd.

Fleisher, B. M and J. Chen (1997), "The Coast-Noncoast Income Gap, Productivity and Regional Economic Policy in China", Journal of Comparative Economics, 25, 220-236.

Fry, M.J. (1980), 'Saving, Investment, Growth and the Cost of Financial Repression', World Development, 18, 317-327.

Galbis, V. (1977), 'Financial Intermediation and Economic Growth in Less-Developed Countries: a Theoretical Approach', Journal of Development Studies, 13, 58-72.

Gallo, J. L. and C. Ertur (2003), "Exploratory Spatial Data Analysis of the Distribution of Regional per Capita GDP in Europe, 1980-1995”, Papers in Regional Science, 82, 175-201.

Garrett, T. A., G. A. Wagner and D. C. Wheelock (2007), " Regional Disparities in the Spatial Correlation of State Income Growth, 1977-2002”, Annals of Regional Science, 41, 601-618.

Groenewold, N., G. Lee and A. Chen (2007a), "Regional Output Spillovers in China: Estimates from a VAR Model”, Papers in Regional Science, 86, 101-122.

Groenewold, N., G. Lee and A. Chen (2007b), "Inter-Regional Spillovers in China: The Importance of Common Shocks and the Definition of the Regions", China Economic Review, forthcoming; doi:10.1016/j.chieco.2007.10.002.

Hao, C. (2006), 'Development of Financial Intermediation and Economic Growth: The Chinese Experience', China Economic Review, 17, 347-362.

Heilig, G. K. (2006), "Many Chinas? The Economic Diversity of China's Provinces", Population and Development Review, 32, 147-61.

Im, K. S., M. H. Pesaran and Y. Shin (2003), "Testing for Unit Roots in Heterogeneous Panels", Journal of Econometrics, 115, 53-74.

Jin, J. and Zou, H.,2005. 'Fiscal decentralization, revenue and expenditure assignments, and growth in China', Journal of Asian Economics, 16, 1047-1064. 
Kanbur, R. and X. Zhang (1999), "Which Regional Inequality? The Evolution of RuralUrban and Inland-Coastal Inequality in China from 1983 to 1995", Journal of Comparative Economics, 27, 686-701.

Kao, C. (1999), “Spurious Regression and Residual-Based Tests for Cointegration in Panel Data", Journal of Econometrics, 90, 1-44.

Kapur, B.K. (1976), 'Alternative Stabilization Policies for Less-Developed Economies', Journal of Political Economy, 84(4), 777-795.

King, R.G. and Levine, R. (1993), 'Finance, Entrepreneurship and Growth: Theory and Evidence', Journal of Monetary Economics, 32, 513-542.

Kuznets, S. (1955), "Economic Growth and Income Inequality", American Economic Review, 45, 1-28.

La Porta R., Lopez-de-Silanes, F. and Shleifer, A. (2002), 'Government Ownership of Commercial Banks', Journal of Finance, 57, 265-301.

Lai, M., Peng, S. and Bao Q., 2006. 'Technology spillovers, absorptive capacity and economic growth', China Economic Review, 17, 300-320.

Lee, C. (2005), "Energy Consumption and GDP in Developing Countries: A Cointegrated Panel Analysis", Energy Economics 27, 415-427.

Lee, C. and C. Chang (2007 in press), "Energy Consumption and Economic Growth in Asian Economies: A More Comprehensive Analysis Using Panel Data”, Resource and Energy Economics, doi:10.1016/j.reseneeco.2007.03.003.

Levine, R. (2005), 'Finance and Growth: Theory and Evidence', Chapter 12 in P. Aghion and S.N. Durlauf (eds), Handbook of Economic Growth, Volume 1A, Elsevier, 865-934.

Levine, R. and Zervos, S. (1998), 'Stock Markets, Banks and Economic Growth', American Economic Review, 88, 537-558.

Lu, D. (2002), "Rural-Urban Income Disparity: Impact of Growth, Allocative Efficiency and Local Growth Welfare", China Economic Review, 13, 419-429.

Maddala, G. S. and S. Wu (1999), “ A Comparative Study of Unit Root Tests with Panel Data and a New Simple Test", Oxford Bulletin of Economics and Statistics, 61, 631-52. 
Mathieson, D.J. (1980), 'Financial Reform and Stabilization Policy in a Developing Economy', Journal of Development Economics, 7, 359-395.

McKinnon, R.I. (1973), Money and Capital in Economic Development, Brookings Institution, Washington, D.C.

Pedroni, P. (1999), "Critical Values for Cointegration Tests in Heterogeneous Panels with Multiple Regressors", Oxford Bulletin of Economics and Statistics, 61, 653-70.

Pedroni, P. (2000), "Fully Modified OLS for Heterogeneous Cointegrated Panels", Advances in Econometrics, 15, 93-130.

Pedroni, P. (2001), "Purchasing Power Parity Tests in Cointegrated Panels", Review of Economics and Statistics, 83, 727-731.

Pedroni, P. (2004), "Panel Cointegration: Asymptotic and Finite Sample Properties of Pooled Time Series Tests with an Application to the PPP Hypothesis", Econometric Theory, 20, 579-652.

Pedroni, P. and J. Y. Yao (2006), "Regional Income Divergence in China", Journal of Asian Economics, 17, 294-315.

Petrakos, G. and Y. Saratsis (2000), "Regional Inequalities in Greece", Papers in Regional Science, 79, 57-74.

Shaw, E. (1973), Financial Deepening in Economic Development, Oxford University Press, Oxford.

Silveira-Neto, R. and C. R. Azzoni (2006), "Location and Regional Income Disparity Dynamics: The Brazilian Case”, Papers in Regional Science, 85, 599-613.

Soytas, U., R. Sari and B. T. Ewing (2007), "Energy Consumption, Income and Carbon Emissions in the United States", Ecological Economics, 62, 482-489.

Stiglitz, J.E. and Weiss, A. (1981), 'Credit Rationing in Markets with Imperfect Information', American Economic Review, 71, 393-410.

Taylor, J.B. (1983), Structuralist Macroeconomics, Basic Books, New York, USA.

Toda, H. Y. and T. Yamamoto (1995), “ Statistical Inference in Vector Autoregressions with Possibly Integrated Processes", Journal of Econometrics, 66, 225-250.

Van Wijnbergen, S. (1982), 'Stagflationary Effects of Monetary Stabilization Policies: A Quantitative Analysis of South Korea', Journal of Development Economics, 10, $133-164$. 
Van Wijnbergen, S. (1983a), 'Interest rate management in LDCs', Journal of Monetary Economics, 12, 433-452.

Van Wijnbergen, S. (1983b), 'Credit policy, inflation and growth in a financially repressed economy', Journal of Development Economics, 13, 45-65.

Wan, G. and X. Zhang (2006), "Introduction: Rising Inequality in China”, Journal of Comparative Economics, 34, 631-33.

Williamson, J. (1965), "Regional Inequality in the Process of National Development", Economic Development and Cultural Change, 17, 3-84.

Wu, Y. (2004), China's Economic Growth: A Miracle with Chinese Characteristics. London: Routledge Curzon.

Yang, D. T. (2002), “What Has Caused Regional Inequality in China?”, China Economic Review, 13, 331-334.

Yang, G. and M. Li (2004), “"Research on China's Unbalanced Credit Flow and Differential Financial Policy Implementation "Journal of Financial Research (in Chinese with English abstract), No. 291, vol. 2004-9, 119-133.

Yao, S. (2006), 'On economic growth: FDI and exports in China', Applied Economics, $38,339-351$.

Yao. S. and Z. Zhang (2001a), "Regional Growth in China Under Economic Reforms", Journal of Development Studies, 38, 167-186.

Yao, S. and Z. Zhang (2001b), "On Regional Inequality and Diverging Clubs: A Case Study of Contemporary China”, Journal of Comparative Economics, 29, 466-484.

Ying, L. G. (2000), “Measuring the Spillover Effects: Some Chinese Evidence”, Papers in Regional Science, 79, pp. 75-89.

Ying, L. G. (2006), “ An Institutional Convergence Perspective on China's Recent Growth Experience: A Research Note”, Papers in Regional Science, 85, 322-330.

Zhang, X., 2006. 'Fiscal decentralization and political centralization in China: Implications for growth and inequality', Journal of Comparative Economics, 34, 713-726. 
Table 1: Sources of Funds, China, 1986 and 2004

\begin{tabular}{|lrrrr|}
\hline & \multicolumn{2}{c}{1986} & \multicolumn{2}{c|}{2004} \\
\cline { 2 - 5 } Funding source & $100 \mathrm{~m}$ RMB & \% of total & $100 \mathrm{~m}$ RMB & \% of total \\
\hline State-owned commercial banks & 6579 & 92.05 & 94735 & 61.17 \\
Joint-stock commercial banks & 0 & 0.00 & 28859 & 18.64 \\
City commercial banks & 0 & 0.00 & 9045 & 5.84 \\
Rural commercial banks & 0 & 0.00 & 483 & 0.31 \\
Urban credit cooperatives & 0 & 0.00 & 979 & 0.63 \\
Rural credit cooperatives & 569 & 7.95 & 19238 & 12.42 \\
Stock market & 0 & 0.00 & 1520 & 0.98 \\
\hline Total & 7148 & 100.00 & 154859 & 100.00 \\
\hline Note: Source of data for bank loans: Almanac of China's Finance and Banking; source of data for stock \\
market capital raisings: China Securities Regulatory Commission.
\end{tabular}


Table 2: The Provincial Distribution of Real GDP and Loans

\begin{tabular}{|c|c|c|c|}
\hline \multirow[b]{2}{*}{ Province } & \multicolumn{3}{|c|}{ Ratio of Provincial to National } \\
\hline & Real GDP & $\begin{array}{l}\text { State-Owned Bank } \\
\text { Loans }\end{array}$ & Rural Credit Loans \\
\hline Anhui & 0.5086 & 0.3467 & 0.3843 \\
\hline Beijing & 3.8492 & 7.1536 & 3.0960 \\
\hline Fujian & 1.4615 & 0.9493 & 0.6485 \\
\hline Gansu & 0.6788 & 0.7245 & 0.6668 \\
\hline Guangdong & 1.6018 & 1.4274 & 1.7942 \\
\hline Guangxi & 0.5789 & 0.8309 & 0.6857 \\
\hline Guizhou & 0.2723 & 0.3979 & 0.2383 \\
\hline Hebei & 1.3405 & 0.8301 & 1.4656 \\
\hline Heilongjiang & 1.1452 & 0.7735 & 0.3675 \\
\hline Henan & 0.6401 & 0.3780 & 0.6006 \\
\hline Hubei & 0.8610 & 0.5502 & 0.3912 \\
\hline Hunan & 0.5864 & 0.3885 & 0.4634 \\
\hline Jiangsu & 1.9597 & 1.4591 & 1.1882 \\
\hline Jiangxi & 0.6638 & 0.5253 & 0.4756 \\
\hline Jilin & 1.1408 & 1.0260 & 0.5995 \\
\hline Liaoning & 2.2627 & 1.7458 & 1.4098 \\
\hline Neimenggu & 1.2514 & 1.0278 & 0.6901 \\
\hline Qinghai & 0.7220 & 0.9984 & 0.3202 \\
\hline Shandong & 1.4214 & 0.7608 & 1.2661 \\
\hline Shanghai & 8.2476 & 10.7969 & 4.1504 \\
\hline Shanxi & 0.9144 & 0.9798 & 1.5042 \\
\hline Shaanxi & 0.8561 & 0.8272 & 0.9938 \\
\hline Sichuan & 0.7343 & 0.6335 & 0.7314 \\
\hline Tianjin & 3.5969 & 3.8200 & 3.5317 \\
\hline Xinjiang & 0.8930 & 0.6890 & 0.3872 \\
\hline Yunnan & 0.4954 & 0.4705 & 0.4541 \\
\hline Zhejiang & 2.0280 & 2.0112 & 2.5533 \\
\hline Correlation with RGDP & 1.0000 & 0.9640 & 0.8812 \\
\hline Coefficient of variation & 1.0586 & 1.4541 & 0.8923 \\
\hline
\end{tabular}

Note: Data for real GDP are taken from China Statistical Yearbook and those for drs and drr from various issues of the Almanac of China's Finance and Banking. 
Table3: Panel unit root test results

\begin{tabular}{|c|c|c|c|}
\hline Variable & Trend/No trend & ADF-Fisher & IPS \\
\hline \multirow{2}{*}{ drg } & No trend & $\begin{array}{c}11.1544 \\
(1.0000) \\
\end{array}$ & $\begin{array}{r}22.4786 \\
(1.0000) \\
\end{array}$ \\
\hline & trend & $\begin{array}{c}38.1112 \\
(0.9501)\end{array}$ & $\begin{array}{l}9.66185 \\
(1.0000)\end{array}$ \\
\hline \multirow[b]{2}{*}{ drr } & No trend & $\begin{array}{l}7.30947 \\
(1.0000)\end{array}$ & $\begin{array}{l}14.4492 \\
(1.0000)\end{array}$ \\
\hline & trend & $\begin{array}{c}39.7514 \\
(0.9263)\end{array}$ & $\begin{array}{l}5.09048 \\
(1.0000)\end{array}$ \\
\hline \multirow[b]{2}{*}{ drs } & No trend & $\begin{array}{c}34.6235 \\
(0.9814)\end{array}$ & $\begin{array}{l}9.17449 \\
(1.0000)\end{array}$ \\
\hline & trend & $\begin{array}{c}43.7488 \\
(0.8393)\end{array}$ & $\begin{array}{r}4.32627 \\
(1.0000)\end{array}$ \\
\hline \multirow{2}{*}{ drk } & No trend & $\begin{array}{l}17.5572 \\
(1.0000)\end{array}$ & $\begin{array}{l}11.1721 \\
(1.0000)\end{array}$ \\
\hline & trend & $\begin{array}{l}50.2145 \\
(0.6212)\end{array}$ & $\begin{array}{l}4.43342 \\
(1.0000)\end{array}$ \\
\hline \multirow[t]{2}{*}{$\mathrm{D}(\mathrm{drg})$} & No trend & $\begin{array}{l}120.717 \\
(0.0000)\end{array}$ & $\begin{array}{r}-1.90149 \\
(0.0286)\end{array}$ \\
\hline & trend & $\begin{array}{l}135.259 \\
(0.0000)\end{array}$ & $\begin{array}{r}-5.52120 \\
(0.0000) \\
\end{array}$ \\
\hline \multirow[t]{2}{*}{$\mathrm{D}(\mathrm{drr})$} & No trend & $\begin{array}{l}167.673 \\
(0.0000)\end{array}$ & $\begin{array}{r}-7.76529 \\
(0.0000) \\
\end{array}$ \\
\hline & trend & $\begin{array}{l}198.415 \\
(0.0000)\end{array}$ & $\begin{array}{r}-10.3730 \\
(0.0000)\end{array}$ \\
\hline \multirow[t]{2}{*}{$\mathrm{D}(\mathrm{drs})$} & No trend & $\begin{array}{l}230.083 \\
(0.0000)\end{array}$ & $\begin{array}{r}-11.6642 \\
(0.0000)\end{array}$ \\
\hline & trend & $\begin{array}{l}177.504 \\
(0.0000)\end{array}$ & $\begin{array}{l}-9.3090 \\
(0.0000)\end{array}$ \\
\hline \multirow[t]{2}{*}{$\mathrm{D}(\mathrm{drk})$} & No trend & $\begin{array}{l}154.270 \\
(0.0000)\end{array}$ & $\begin{array}{c}-6.05923 \\
(0.0000)\end{array}$ \\
\hline & trend & $\begin{array}{r}-4.68592 \\
(0.0000)\end{array}$ & $\begin{array}{c}130.199 \\
(0.0000)\end{array}$ \\
\hline
\end{tabular}

Note: the variables are defined as follows: drg is the difference between real per capita GDP for a province and that for the country as a whole, drr, drs and drk are defined similarly for loans by rural credit cooperatives, loans by state-owned commercial banks and capital formation. $\mathrm{D}(\mathrm{X})$ is the first difference of X. 
Table 4: Panel cointegration test results

Statistic

Pedroni:

Panel-v

p-value

Panel-rho

0.0000

Panel-PP

0.0021

Panel-ADF

0.3980

Panel-ADF

0.0112

Group-PP

0.0000

Group-PP

0.2639

Group-ADF

0.0171

Kao:

$\mathrm{ADF}$

0.0252

Fisher-Johansen:

Trace:

No cointegration $\quad 0.0000$

At most 1 cointegrating vector $\quad 0.0000$

At most 2 cointegrating vectors $\quad 0.0006$

Eigenvalue:

No cointegration $\quad 0.0000$

At most 1 cointegrating vector $\quad 0.0000$

At most 2 cointegrating vectors $\quad 0.0567$

Note: the tests are for cointegration amongst the four variables $\mathrm{drg}$, $d r k, d r r, d r s$ defined in the note to Table3. For the Pedroni and

Kao tests the null hypothesis is that there is no cointegration amongst the four variables. The null for the Fisher-Johansen test is as stated. 
Table 5: Long-run causality to output disparity

\begin{tabular}{|c|c|c|c|c|c|c|}
\hline & & & & \multicolumn{3}{|c|}{ Causality (p-value) } \\
\cline { 5 - 7 }$k$ & intercept & trend & slopes & $d r k$ & $d r r$ & $d r s$ \\
\hline 1 & common & none & common & 0.0004 & 0.6125 & 0.1546 \\
\hline 1 & common & common & common & 0.0004 & 0.6258 & 0.1605 \\
\hline 1 & common & none & individual & 0.0031 & 0.0037 & 0.0091 \\
\hline 1 & individual & none & individual & 0.0280 & 0.8419 & 0.9999 \\
\hline 1 & common & common & individual & 0.0034 & 0.0040 & 0.0096 \\
\hline 1 & individual & common & individual & 0.0266 & 0.8728 & 0.9999 \\
\hline 1 & individual & individual & individual & 0.0854 & 0.9999 & 0.9999 \\
\hline 2 & common & none & common & 0.0660 & 0.0243 & 0.0020 \\
\hline 2 & common & common & common & 0.0671 & 0.0249 & 0.0021 \\
\hline 2 & common & none & individual & 0.3486 & 0.0010 & 0.1109 \\
\hline 2 & individual & none & individual & 0.9372 & 0.1589 & 0.2260 \\
\hline 2 & common & common & individual & 0.3681 & 0.0012 & 0.1897 \\
\hline 2 & individual & common & individual & 0.9373 & 0.1805 & 0.2361 \\
\hline 2 & individual & individual & individual & 0.0001 & 0.0018 & 0.0000 \\
\hline
\end{tabular}

Note: the tests are of the hypothesis that $d r k(d r r, d r s)$ do not cause $d r g$ in the long run; $k$ refers to the lag length in the testing equation; "common" indicates that the coefficient is constrained to be equal across all provinces and "individual" indicates that the relevant coefficient is allowed to differ across provinces.

Table 6: Short-run causality to output disparity

\begin{tabular}{|l|l|}
\hline Causation & Wald statistic (p-value) \\
\hline$d r k$ to $d g r$ & $37.9580(0.0000)$ \\
\hline$d r r$ to $d r g$ & $87.2323(0.0000)$ \\
\hline$d r s$ to $d r g$ & $89.0760(0.0000)$ \\
\hline
\end{tabular}

Note: the tests are of the hypothesis that $d r k(d r r, d r s)$ do not cause $d r g$ in the short run. The test statistics are derived from a VECM with one lag and an intercept in both the VECM equations and the cointegrating vector as well as a trend term in the cointegrating vector. 


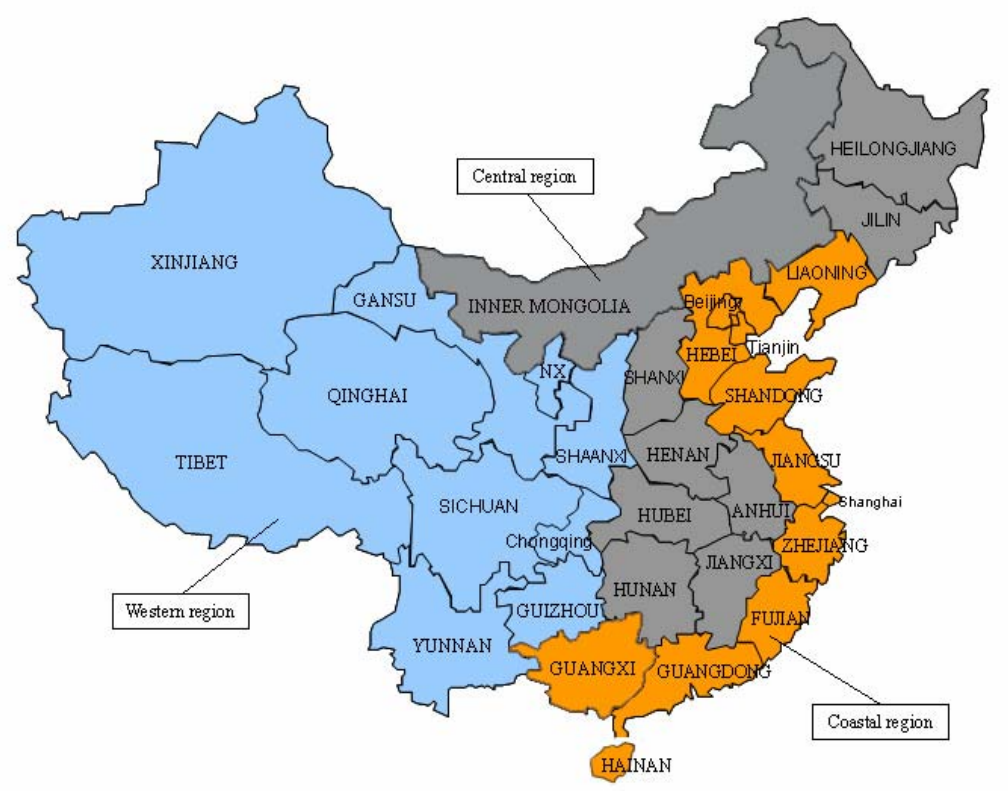

Figure 1: Provinces and three regions of mainland China 